\title{
Polymer Processing Society 19th Annual Meeting 参加報告
}

\author{
後 藤 康 $*^{*}$
}

第 19 回 Polymer Processing Society（PPS）の年次大 会が，2003 年 7 月 7 日〜10日の日程で，オーストラリア のメルボルンにある Sheraton Tower Southgate ホテルで 開催された。オーストラリア大陸東部最南端に位置するこ の街は，オーストラリア第 2 の大都市（430万人）であり， また，同国の金融の中心である．贝人が最初に入植してき たシドニーと異なり，イギリスの貴族が最初に移民してき たという自負があり，プライドが高いらしい。オーストラ リアの古い街並みと近代的な高層ビルの両者が混在した面 白い街である（図 1).

年次大会は, 7 月 7 日夕方よりウェルカムパーティーで 始まった，その折，大会の Chairmanである Royal Melbourne Institute of Technology 大学の S. N. Bhattacharya 教授の挨拶があり, 本大会は 32 力国からの参加がある真 にインターナショナルな学会であることを述べられていた。 また，パーティーの終盤には，アボリジニの踊りが披露さ れ，楽しい一時を過ごさせていただいた。講演は，8 日よ り 3 日間の日程で午前中前半は, 毎日 2 件の招待講演（計 6 件: 表 1), 午前後半と午後は各セッションのキーノート レクチャーおよび口頭発表があった。 ポスターセッション は，8日の $17 ： 00-19 ： 00$ の時間带に設けられた。昨年度

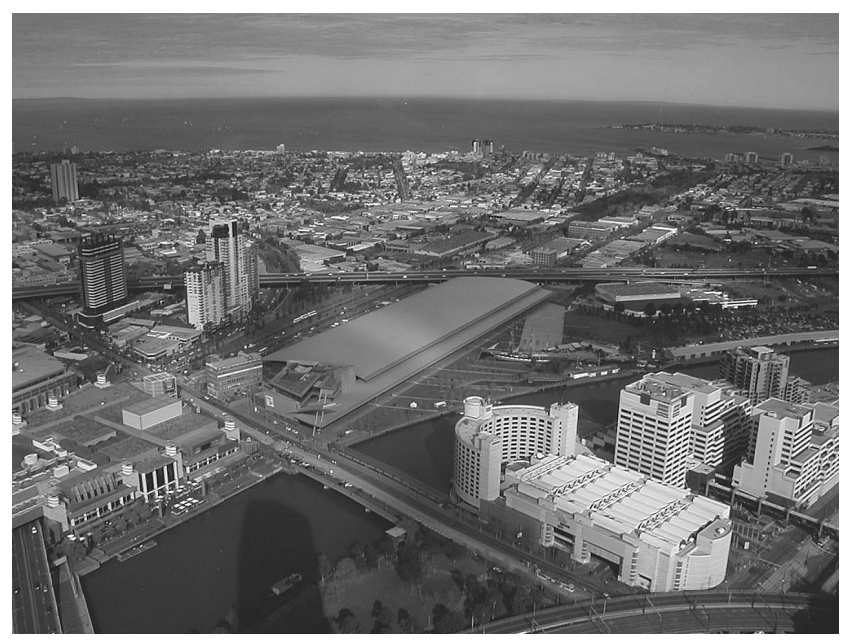

図 1 市内の高層ビルから眺めたメルボルン市街

\footnotetext{
* Gotoh, Yasuo

信州大学瀻維学部繊維システム工学科

上田市常田 3-15-1（テ386-8567）

2003.7.30 受理
}

\section{表 1 招待講演}

1. Reinforced and Toughened Polyamide 6 Donald Paul, University of Texas, U.S.A.

2. From Science to Commercial Products-25 Years of Molding Simulation

Roland Thomas, Moldflow Corporation, Australia

3. Structure Development in Polyolefin Processing James L. White, Institute of Polymer Engineering, University of Akron, U.K.

4. Diffuse Interface Modelling of the Rheology of Immiscible Polymer Blends

Han E.H. Meijer, Eindhoven University of Technology, Netherlands

5. Engineering Plastics via Nano-Structure Control in TwinScrew Extruder

Takashi Inoue, Yamagata University, Department of Polymer Science and Engineering, Japan

6. Influence of Structural Parameters on The Properties Of Styrene Butadiene Rubber Based Nanocomposites Anil K. Bhowmick, Rubber Technology Center, Indian Institute of Technology, Kharagpur, India

\section{表 2 セクション毎の講演数（うちポスター発表）}

\section{Composites}

Blends and Alloys

Rheology and Rheometry

Mixing and Compounding

Reactive Processing/Foams

Injection Moulding

Blow Moulding and Thermoforming

Morphology, Structure \& Properties

Modelling and Simulation

Films/Fibres

Extrusion and Coating

New Materials and Processes

; 21 (5)

;20(6)

; 21 (4)

; $17 \quad$ (6)

; 23 (5)

; 22 (3)

; 5 (1)

; 27 (2)

; 19 (3)

; 20 (3)

; 12 (3) ; 25 (9)
のPPS 18 と比較すると, 発表件数は半減した（約 230 件）. 地理的なことも関係していると思うが, SARSによるとこ ろが大きいであろう。 その中で, 日本からの講演件数は, 昨年度とほぼ同じ件数（42 件）を維持し，健闘が光った. また, 各研究分野に特に大きな偏りがなく, 材料, 成形加 工, 機械など比較的広い分野の研究者が集う学会であると いう印象を受けた（表 2 参照）.

著者は, 日本で開催される年次大会も含めてポリマープ ロセッシング学会関係の会議への参加は今回初めてで, 著 


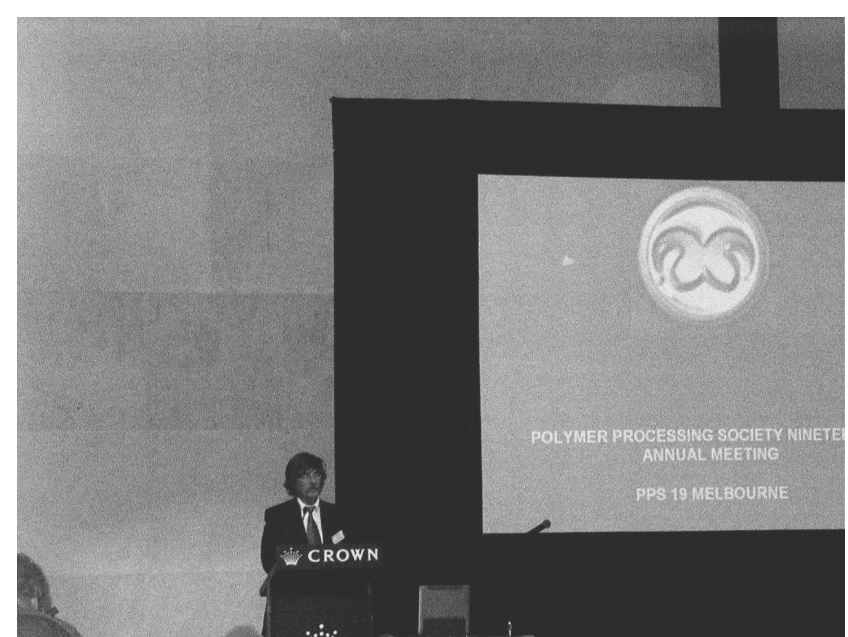

図 2 バンケットで挨拶される Meijer 会長

名な先生方の名前すら知らない状況なので，この参加報告 を書かせていただくことを誠におこがましく思っている. 多くの重要な研究発表を聞き逃している点, 興味が偏って いる点をご容赦いただきたい.

著者の興味ある分野（ナノコンポジット）として，Composites, New Materials and Processes を中心に拝聴した。 コンポジット材料は，マクロレベルで組み合わせたコンポ ジット（高分子ブレンドや無機 (繊維) 充填プラスチック などの製造技術や物性評価法など), およびナノコンポジッ トが中心であった.ナノコンポジットについては, 講演の 多くが粘土鉱物や層状シリケートなどの易剥離型層状無機 物をポリマー中に導入した系を取り扱った研究が中心で あった（約 20 件). 主として melt compoundingによるナ ノ分散化によって，種々のポリマー中への有機修飾化層状 無機物の導入がはかられている. 全体としては, 剛性率や ガスバリヤ性の物性などに関しては, 従来から報告されて いる結果と大きくは変わっていない印象を受けたが，発表 件数の多さから，テクノロジーの面白さのみならず，応用 へのポテンシャルの高い材料であると感じた。

Shimonik らは，モンモリロナイト（MMT）にインター カレートさせるために，よく利用されている末端の官能基 が異なる 2 種類の有機化合物 cetylpyridinium (CP) およ び cetytrimethylammonium（CTA）を用いて, 分子動力 学シミュレーションから, MMT 層間中での構造や MMT に対する相互作用の大きさを検討した。 その結果, 層間中 では $\mathrm{CP}$ や CTA の有する $\mathrm{C}_{16} \mathrm{H}_{33}$ 基が乱れを有した液体状 でしかも単層で存在すること，また，MMTとの相互作用 は, CTA の有する 4 級アンモニウム基の方が大きいこと を示した．未検討の層状無機物を有機修飾する際に，指針 となる方法となろう.

Okamoto らは，ナイロン6/クレイの組み合わせが，溶 融下, せん断応力により, 顕著なレオペクシーを示すこと, そしてポリマー中に分散されたクレイが配向していること を報告した。このことは，クレイを等方的に分散させるだ けでなく, 異方性分散を付与して, 方向によって物性の異
なる材料設計を行う上での指針として重要であると考えら れる。

Simon らは, ハイパーブランチポリマーやデンドリマー とクレイとの組み合わせを検討している。これらのポリ マーは, 生産コストは恐らく相当高く, また力学的性質も 線状ポリマーに比べて劣るため，実用可能な材料とは言い 難いが，新素材を創出しようという試みは，一聴衆として は楽しいものである.

炭素材料を取り扱った報告は少なかった。Wang らは, Pan-millingによって, PP 中でグラファイトを層間剥離さ せてナノ分散させた. $5 \mathrm{wt} \%$ のグラファイトを添加した材 料は，常法により混合して作製した場合と比較して，10 桁も電気伝導度を上昇させることに成功した。ナノ分散が, 物性に良い影響を及ぼした好例であり，簡単な方法である ので応用展開に期待したい.

現在，ホットな材料であるカーボンナノチューブを取り 扱ったナノコンポジットの発表件数は，きわめて少なく， $1 ， 2$ 件，散見される程度であった. Pötschke らは，Multi wall carbon nanotube (MWNT) をポリカーボネートに導 入した。コンポジットの電気抵抗は, MWNTの導入量が $1.0 \mathrm{wt} \%$ と $1.5 \mathrm{wt} \%$ の間に大きな閾值が存在し, $1.5 \mathrm{wt} \%$ の導入で $10^{2} \Omega \cdot \mathrm{cm}$ にまで低下（10桁以上の低下）させ ることができた。学的性質に関しては, $15 \mathrm{wt} \%$ の MWNT の導入によっても，たかだか弾性率を 1.3 倍程度 までしか上げることができなかった．カーボンナノチュー ブが非常に高い弾性率を有することから考えると, 単純な ブレンドでは, MWNT とポリマー間の界面に応力伝達に 必要な接着性が存在していないことは明らかである. カー ボンナノチューブ自身が, 非常に高いポテンシャルを持つ 材料であるので，性能発現に有効な（ポリマーに対して強 い相互作用をもたらす）コンパウンディング方法の開発を 望む.

以上, ナノコンポジットに関しての学会報告を行ったが, この分野に対して，新規な機能性無機物の探索，あるいは アイデアに基づいた新材料の設計などの試みが欲しいとい う印象を強く持った。本学会の今後に期待したい.

初参加の者として, 学会全体としての印象としては, 小 さいながら（というより，小さいがゆえに）, 議論が活発 になされ，また研究者同士の交流がより濃密なものとなっ ている良い学会であると感じた.

7 月 9 日のバンケットでの PPS 会長 Meijer 先生のご挨 拶の写真を示す (図 2)。挨拶の折，JSW の酒井忠基氏が 次期会長に就任されることが紹介された。 日本人としては 2 人目とのことで, 大変名誉なことである. ところで私事 で恐縮だが，この原稿の執筆中，10 年前の修士課程の頃 に, 大学の研究室で Meijer 先生相手に大汗をかきながら 著者の研究を紹介させていただいたことが，完全に忘れて いた記憶の中から蘇った。世間は狭いものだ.

来年の PPS-20 は， 2004 年 6 月 20 日〜 24 日の日程で, アメリカ・アクロンで開催される. 日本から多くの研究者 が参加されることを希望し, 報告を終わらせていただく. 